\title{
EMPLOYEE PRIVILEGES IN THE POLISH TOBACCO INDUSTRY IN A PERIOD OF POLISH PEOPLE'S REPUBLIC
}

\begin{abstract}
Described privileges of determined employee groups in the Polish tobacco industry in a period of Polish People's Republic on example of Kraków plants arose largely from the statute law, although not without meaning carried out its interpretation, by workers self-management and Company's Dispute Adjudication Boards (CDAB). It was possible to notice the sign of appropriating privileges by determined employees groups not-arising from the existing law, but being a sign of aspirations to ensure a higher position for oneself in the unit through certain acquaintances and in consequence achieving common benefits, etc. informally. The article constitutes only a starting point for further in-depth studies covering employee issues in all tobacco industry in Poland.
\end{abstract}

Keywords: privileges, tobacco industry, Kraków plants, Polish People's Republic, employee issues

doi:10.1515/sho-2015-0006

Institutions, which enjoyed considerable privileges in the Polish industrial plants in a period of Polish People's Republic, thus also in tobacco enterprises, were Company's Dispute Adjudication Boards (CDAB, Zakładowa Komisja Rozjemcza). Many times they decided about the fate of employees, who appealed to them in different issues, even in such matters which were beyond $\mathrm{CDAB}$ competence. Employees regarded them as the only alternative of defense against injustice or harm, which they experienced, in their view, in the workplace, whether on a part of management abusing its power or employees, who claimed the right to manage others. CDAB apart from advice of the Branch Office Councils, Works Councils and Council Workers, they became an important link in the reality of everyday life of the socialist workplace. 
The legal basis for creation of Company's Dispute Adjudication Boards was a Decree from February 24, 1954. Boards were supposed to contribute for fast solving labour disputes associated with performance of work as far as possible in the workplace and with direct participation of relevant parties. We can read in the Decree that it was required in favor to interests of working masses and good of the national economy. Only employees of the given enterprise could entered into its membership (employing at least 100 employees), in which was appointed. Members of local works council and manager of the enterprise were entitled to this privilege. CDAB proceedings were initiated upon the employee's request. Statements of the board were issued unanimously and could be appealed to the Main Board of relevant trade union, and the one approved or repealed them, when it was issued in violation of applicable laws and regulations. In case of repealing the employee was entitled to a right to notification, within 14 days of the notification to competent court. Provided such a notification wasn't reported, the Main Board referred the matter to CDAB for reconsideration. ${ }^{1}$ Summing up, it is possible to state that the purpose of appointing Company's Dispute Adjudication Boards in the workplaces was to create favorable possibilities of pursuing civil law (property) claims for employees, resulting from the employment. ${ }^{2}$

In Polish tobacco industry the Cracow plants had an important role in the entire period of Polish People's Republic. Up to 1958 there were three separate tobacco enterprises: Cracow Cigarettes Factory (CCF, Krakowska Wytwórnia Papierosów) by Dolnych Młynów Street, “Czyżyny” Cigaret-

${ }^{1}$ Dekret z dnia 24 lutego 1954 r. o zakładowych komisjach rozjemczych [Decree of February 24, 1954 on company disputes committees], Journal of Laws [Dz. U.] 1954, no. 10, item 35. As Zofia Heinrich wrote, according to Decree the dispute adjudication board is "an organ reinforcing the socialist law-abidingness in the workplaces through direct realization of applicable standards of the labour law in specific cases, as well as by developing the legal awareness amongst the crew and managements of the workplaces, by pointing out the proper way of proceeding". See: Heinrich Zofia, Wybrane zagadnienia działalności Zakładowej Komisji Rozjemczej [Selected issues regarding the activities of the Company Disputes Committee], [in:] Hirszowicz Maria [ed.], Człowiek w organizacji przemystowej. Socjologiczna monografia zakładu przemystowego [Man in an industrial organization. Sociological monograph on an industrial plant], PWN, Warszawa 1965, p. 267. However, workers of the Polish industrial plants sometimes complained that complains reported to the dispute adjudication board dragged for months. See: Seidler Barbara, Winteresie robotniczej klasy [On behalf of the working class], Przegląd Kulturalny, no. 20/1962, p. 2.

2 Krąkowski Ludwik, Zakładowe Komisje Rozjemcze. Komisje Rozjemcze a Inspekcja Pracy [Company disputes committees. Disputes committees versus the Labour Inspectorate], Przegląd Związkowy, no. 1, 1955, p. 45. 
tes Factory (CZCF, Wytwórnia Papierosów “Czyżyny”) in Cracow-Czyżyny and Cracow Industrial Tobacco Factory (CITB, Krakowska Wytwórnia Tytoniu Przemysłowego; earlier know as Cultivation of the Tobacco Plant Unit [Zakład Uprawy Tytoniu]) also in Cracow-Czyżyny. Based on Order no. 34 of Minister of the Food Industry and Acquisition from March 3, 1958 the CITB was merged with CZCF, and one enterprise was formed under the name of Tobacco Industry Plant (TIP, Zakłady Przemysłu Tytoniowego) in Cracow-Czyżyny. ${ }^{3}$ In March 27, 1959, by Order no. 302 of Minister of the Food Industry and Acquisition, to TIP the $\mathrm{CCF}^{4}$ was included. Ultimately, from three independent Cracow tobacco plants arose one conglomerate under the name of Tobacco Industry Plant in Cracow, producing both the industrial tobacco and cigarettes. ${ }^{5}$

Taking into account the size and meaning for the Polish tobacco industry of Cracow plants, it is possible to assume that issues concerning their

${ }^{3}$ Archiwum Narodowe w Krakowie. Ekspozytura w Spytkowicach [The National Archives in Krakow. Spytkowice Branch] (ANKES), Zakłady Przemysłu Tytoniowego SA w Krakowie [The Zakłady Przemysłu Tytoniowego SA tobacco company in Kraków] (ZPTK), Zakłady Przemysłu Tytoniowego w Krakowie-Czyżynach [The Zakłady Przemysłu Tytoniowego tobacco company in Kraków-Czyżyny] (ZPTKC), 1. Zarządzenie wprowadzające tymczasową strukturę organizacyjną w ZPT "Czyżynach" 1958 [A regulation introducing temporary management in the "Czyżyny" tobacco plant, 1958], Zarządzenie wewnętrzne, no. 3, p. 1.

${ }^{4}$ ANKES, ZPTK, Zakłady Przemysłu Tytoniowego w Krakowie (ZPTwK). Spis sprawozdawczo-odbiorczy [The Zakłady Przemysłu Tytoniowego SA tobacco company in Kraków. Reporting and receiving inventory of the file], act no. 24, 24/25, Skoroszyt 2. 1959: Protokół połączenia Krakowskiej Wytwórni Papierosów i Zakładów Przemysłu Tytoniowego w Czyżynach [The Krakowska Wytwórnia Papierosów cigarette factory and the Zakłady Przemysłu Tytoniowego tobacco company in Czyżyny merger protocol], Zarządzenie no. 302 Ministra Przemysłu Spożywczego i Skupu z dn. 27 III 1959 r. w sprawie połączenia przedsiębiorstw państwowych pod nazwą: 1) Zakłady Przemysłu Tytoniowego w Krakowie-Czyżynach, 2) Krakowska Wytwórnia Papierosów. [Ministry of Food Industry and Purchase Ordinance no. 302 of March 27, 1959 on the merger of the following state companies: 1) The Zakłady Przemysłu Tytoniowego tobacco company in Kraków-Czyżyny 2) the Krakowska Wytwórnia Papierosów cigarette factory].

${ }^{5}$ Archiwum Akt Nowych (AAN), Zjednoczenie Przemysłu Tytoniowego w Warszawie 1953-1980 (ZPT), Zjednoczenie Przemysłu Tytoniowego. Wydz[iał] Planow[ania] i Ekonomiki Produkcji. Rozwój i modernizacja przemysłu tytoniowego w latach od 1956 do 1975 [Tobacco Industry Union in Warsaw 1953-1980, Tobacco Industry Union. Department of Planning and Economics of Production. The development and modernisation of the tobacco industry in the years 1956-1975], 1956/75, sign. 2/34, Rozwój przemysłu tytoniowego w latach 1956-1960 1960 [Tobacco industry development in the years 1956-1960], p. 4; ANKES, ZPTK, ZPTKC, 35. Analiza wyników dział[alności] gosp[odarczej] Centralnego Zarządu Przem[ysłu] Tyt[oniowego] za 1958 r., Analiza wyników działalności gospodarczej za rok $1958 \mathrm{r}$. [Analysis of the economic activity of the Tobacco Industry Central Board for the year 1958. Analysis of economic activity for the year 1958.], p. 1. 
employees, were representative for enterprises of the entire tobacco industry in the country. A veritable treasure of knowledge about all sorts of privileges and everyday problems of CZCF employees constitute CDAB documents. In 1958 its files were intercepted by representative of CDAB at TIP in Cracow-Czyżyny, J. Ziółkowski who also became its chairman. Seizer of materials drafted two notes, in which he emphasized that they had been incomplete, many statements and protocols were missing, apart from that the ones kept were wrote on wrong forms, there were no signatures of board members on documents, etc. He also added that records were unsorted. ${ }^{6}$ Irrespective, these materials documented a lot of employee problems, experienced injustice or harm, sometimes even dramas, which they tried to overcome and still to work at the plant. They constitute also an illustration of everyday employees function at the unit and outside it. Additionally, they also enable to reconstruct and show unofficial employee groups, which enjoyed some privileges (also unofficial), and which had, as it seems, quite large impact on everyday life of the production unit in the Polish People's Republic.

CDAB at CZCF was constituted in May 17, 1954, on its head stood Secretary of Works Council, Henry Siemko. Leon Ulman was his first deputy, and second - Modest Lipecki. Also a care of individual industry branches was entrusted. For the branch of cigarettes production was responsible Siemko, for the branch of tobacco production - Ulman, and for the branch of civil service and technical - Lipecki. Kazimierz Rudnik was responsible for the branch of packing room. It was also established that, if necessary, the board chairman will appoint the adjudicating board. ${ }^{7}$

${ }^{6}$ ANKES, ZPTK, Wytwórnia Papierosów „Czyżyny” w Krakowie-Czyżynach [The „Czyżyny" cigarette factory in Kraków-Czyżyny] (WPC), 342. Zakładowa Komisja Rozjemcza - protokoły i orzeczenia z lat 1954-1958. 1954-1958 [Company disputes committee - minutes and adjudications from the years 1954-1958] (342 ZKR), Notatka [J. Zió1kowskiego], [brak daty dziennej] pażdziernik 1958 r. [Note of J. Ziółkowski, no daily date, October 1958]; It is well known that in the second half of 1958 only four cases were submitted to the Company Disputes Committee in ZPT in Kraków. See: ANKES, ZPTK, WPC, 343. Sprawozdanie z działalności Zakładowej Komisji Rozjemczej za II półrocze 1958. 1959, Formularz Wzór 4. Sprawozdanie z działalności Zakładowej Komisji Rozjemczej za II półr[ocze] 1958. [Report on the activities of the Company Disputes Committee for the second half of 1958. Standard Form 4. Report on the activities of the Company Disputes Committee for the second half of 1958].

7 ANKES, ZPTK, WPC, 342 ZKR, Protokół Zebrania Zakładowej Komisji Rozjemczej przy Wytwórni Papierosów „Czyżyny”, 17 maj 1954 r. [Minutes on the session of the Company Disputes Committee in the "Czyżyny" cigarette factory, May 17, 1954]. 
Very quickly it turned out that the most frequently litigated cases reported to dispute adjudication boards in Polish workplaces were matters resulting from termination of the employment (including disciplinary dismissals) and concerning pays. ${ }^{8}$ The same was in the Cracow unit, where employees treated the CDAB as the last resort before inevitable dismissal, but not always it ended with an expected result.

For example, to CDAB at CZCF an employee Kazimierz Mucha appealed - operating the cigarette machine of Skoda $\mathrm{C} 4 \mathrm{~B}$ with a request to withdraw the dismissal based on article 18 of collective agreement in the work. During board meeting he explained that doesn't know why was dismissed. As it turned out from sources of the management decision, there was a row on the production branch on February 16, 1955, which in the opinion of Mucha was a consequence of rumors of one of the workers, Maria Jurkiewicz, who during the working meeting described him as "shirker and layabout". On recalled day it came to blows from both sides. The branch manager stated that on the next day the injured ostentatiously observed Mucha, thus the one at first vulgarly spoke to her, and then pulled her apron. Then the woman slapped Mucha in the face, and he gave back. However, the branch manager provided a positive opinion about the quality of work, both of them. Witnesses confirmed fisticuffs on the part of feuding employees. During witness statements, one of workers added that the management has special privileges, e.g. the foreman drank beer in the buffet during work, and other played chess. The plant manager stood up on the side of worker and stated that she should be covered with care, and the employee must be dismissed. ${ }^{9}$ However, CDAB admitted that for provoking the row during the work he has been rightly dismissed, because as was argued, for loutish pranks must be severely punishment. Moreover, the Board also came to conclusion that Mucha didn't act alone, he was encouraged by friends, constituting a specific support group for him, and during recalled meeting Jurkiewicz personally didn't criticize him. ${ }^{10}$

8 Jakubowska Michalina, Bielecki Antoni, Komisje rozjemcze po roku działalności [Disputes committees - a year of activity], Przegląd Związkowy, no. 8, 1955, p. 345.

9 There wasn't such a situation that from misunderstandings in the unit between men and women, always the men came without harm, as it was e.g. in PAFAWAG units, where in December 1952 the KC PZPR control team was delegated and such request presented in the report. See: AAN, KC PZPR, sign. 237/XV-7, Sprawozdanie ekipy wyjeżdżającej w sprawie zatrudnienia kobiet na terenie woj. wrocławskiego, 16 grudnia 1952 r. [Field team report regarding the employment of women in Wrocław Voivodship], p. 83-88.

10 ANKES, ZPTK, 342 ZKR, Protokól rozprawy, 19 luty 1955 r. [Minutes of the hearing, February 19, 1955]; Ibidem, Załącznik no. 1 do protokołu, p. 1-2; Ibidem, Orzeczenie 
In other situation $\mathrm{CDAB}$ intervention prevented dismissal from work, employed in the warehouse outlets, Irena Duszyńska who received termination on January $1,1955 .{ }^{11}$ She appealed to CDAB, emphasizing that dismissal reasons weren't known to her. ${ }^{12}$ During board meeting the warehouse manager Bronisław Sypek declared that Duszyńska is charged of poor performance of her duties, and the management suggested her transfer to a different position. According to Duszyńska, nobody made such proposal to her, but at once received termination. She admitted that her mistakes resulted from bad working conditions (poor lighting, little visible numbers, erroneously stuck control cards on cartons, etc.). After being reprimanded (oral and written) the quality of her work underwent improvement, and didn't want to be transferred to other branch, because it included two-shift work, and she participated in training "course in calculators" which she wanted to finish successfully. ${ }^{13}$ It is necessary to emphasize that raising professional qualifications was well perceived by the management board, and from the other side it was an undoubted employee privilege, which often had a specific impact on higher earnings. ${ }^{14}$

Warehouse manager emphasized that although Duszyńska hadn't enjoyed the sympathy amongst employees, he would take her back to the work and personally supervised her, if she declared desire for urgent and attentive work. Due to absent of M. Lipecki the management representative during board meeting, Adam Cisło the chairman of CDAB spoke and stated that Duszyńska should be transferred to other branch, since the work

[Zakładowej Komisji Rozjemczej], 21 luty 1955 r. [Attachment no. 1 to the minutes Company Disputes Committee decision, February 21, 1955], act no. 12/55.

11 ANKES, ZPTK, WPC, 342 ZKR, [Pismo Dyrektora Wytwórni Papierosów w Czyżynach do Ireny Duszyńskiej, 31 grudnia 1954 r. [Letter of the "Czyżyny" cigarette factory manager to Irena Muszyńska, December 31, 1954].

12 ANKES, ZPTK, WPC, 342 ZKR, [Pismo Ireny Duszyńskiej do Komisji Rozjemczej, 7 stycznia 1955 r., rps.]. [Letter of Irena Muszyńska to the Disputes Committee, January 7 , 1955, manuscript].

13 ANKES, ZPTK, WPC, 342 ZKR, Protokół rozprawy Zakładowej Komisji Rozjemczej przy Wytwórni Papierosów w Czyżynach w dniu 10 stycznia 1955 r. [Minutes of the hearing in the Company Disputes Committee of the "Czyżyny" cigarette factory of January 10, 1955].

${ }^{14}$ AAN, ZPT, Zjednoczenie Przemysłu Tytoniowego Wydz[iał] Ekonomiczny. Kompleksowa analiza ekonomiczno-techniczna przem[ysłu] tytoniowego za r. 1960 [Tobacco Industry Union Department of Economics. Comprehensive economic and technical analysis of the tobacco industry for the year 1960], R. 1960., sign. 1/83, Kompleksowa analiza ekonomiczno-techniczna za rok 1960 [Zakładów Przemysłu Tytoniowego w Krakowie] [Comprehensive economic and technical analysis for the year 1960; Tobacco Company in Kraków], no. 36 PF/EE/61, p. 155. 
in magazine demands younger and more energetic person. ${ }^{15}$ Finally, the board stated that termination from the work delivered to the worker was inconsistent with principles included in the collective agreement. It didn't contain number of the personal section, manager signature and stamp, or the reporter of personal section, neither stamp nor signature of the Works Council representatives. However, as for not providing reasons of dismissal in the letter, they stated that such not had to be given, since termination was with 14 day notice. As for transferring to a different position, the board didn't state anything, since it wasn't within their competence. ${ }^{16}$

Extremely significant for relations prevailing in the unit, as well as competence and privileges of workers self-government was another case reported to CDAB. Termination, issued by CZCF director, from the work received Maria Tłustowska - employee of the tobacco production branch. ${ }^{17}$ Legal basis of the decision was Regulation of the President of Polish Republic from March 16, 1928 about the employment agreement. ${ }^{18}$ Tłustowska asked for consideration the case by CDAB, which meeting was held on March 3, 1955. She claimed that she was dismissed unjustly and that all the time, which she worked at the unit, never got any reprimand or even admonish. Next during the board meeting came to an unusual situation when the representative of Branch Office Council, Józefa Galos, admitted peculiar mistake. Well, when she signed Tłustowska dismissal, did it without thinking automatically, signing at the same time a few dismissals. Tłustowska co-workers testified that they don't have any objections to her work; she worked willingly and performed all her duties properly, was friendly and helped others in the work. They expressed a great surprise of Tłustowska termination. Chairman of CDAB, L. Ulman, negatively assessed the work of the Branch Office Council. He stated that instead of interested in employees and their problems, probably they didn't know, for what she was there. ${ }^{19}$ In the light of these facts and heard out opinions,

15 ANKES, ZPTK, WPC, 342 ZKR, Protokół rozprawy Zakładowej Komisji Rozjemczej... [Minutes of the hearing in the Company Disputes Committee...].

16 ANKES, ZPTK, WPC, 342 ZKR, Orzeczenie Zakładowej Komisji Rozjemczej przy Wytwórni Papierosów w Czyżynach, 10 stycznia 1955 r. [The decision of the Company Disputes Committee in the "Czyżyny" cigarette factory, January 10, 1955].

17 ANKES, ZPTK, WPC, 342 ZKR, Pismo Dyrektora Wytwórni Papierosów w Czyżynach do Ob. Marii Tłustowskiej, 26 lutego 1955 r. [Letter of the "Czyżyny" cigarette factory manager to Ms. Maria Tłustowska, February 26, 1955], L.dz. 970/Dpr/55.

18 See: Journal of Laws [Dz. U.] 1928, no. 35, item 324.

19 ANKES, ZPTK, WPC, 342 ZKR, Protokół Zakładowej Komisji Rozjemczej przy Wytwórni Papierosów w Czyżynach, 3 marca 1955 r. [Minutes of the Company Disputes 
CDAB decided to revoke the decision of management board, emphasizing in addition mindlessness of Branch Office Council action, abusing her competence with damage for employees of the unit. ${ }^{20}$

It is necessary to emphasize that competence of Branch Office Council was great, particularly after their extension in 1956. The Branch Office Council in case of misunderstandings between employees was an organ relieving disputes, seeking agreement and consensus. However, when conflict was too serious, the Branch Office Council in order to heal the atmosphere at the unit could decide to transfer a given employee to other branch or even decide to dismiss. A relevant application was referred then to personal section in order to agree in this matter with the branch, which if necessary would take the given employee in, or in order to settle formalities associated with dismissal. Only if the decision issued by the Branch Office Council was incompatible with general regulations by which the unit was guided, could cause damage for the branch or even the plant, or would be unjust for the employee, the Director could deny approval of the decision issued by the Council.

Branch Office Council had the right to decide in discipline matters of the work and what penalty shall apply towards employee with too many missing days. They issued every kind of punishment, including dismissal. The Branch Office Council presented its decision to the personal section, which in turn directed it to the director, and the one with last signature approved the council decision. Moreover, Branch Office Council selected employees standing out to awards from the company fund. The list of such employees was presented to the Works Council. ${ }^{21}$

Committee in the "Czyżyny" cigarette factory, March 3, 1955]; ANKES, ZPTK, WPC, 342 ZKR, Protokół z dnia 3 marca 1955 r. Załącznik no. 1. O trudnościach funkcjonowania rad oddziałowych w zakładach pracy w Polsce [Minutes of March 3, 1955; Attachment no. 1. On difficulties in the functioning of department boards in factories in Poland]. See: Adaszek Jerzy, Rady oddziałowe wciąż niezrozumiane [Department boards still misunderstood], Rada Robotnicza, no. 17, 1960, p. 1-2.

20 ANKES, ZPTK, WPC, 342 ZKR, Orzeczenie [Zakładowej Komisji Rozjemczej przy Wytwórni Papierosów w Czyżynach], 3 marca 1955 r. [The decision of the Company Disputes Committee in the "Czyżyny" cigarette factory, January 10, 1955], act no. 14/55.

${ }^{21}$ ANKES, ZPTK, WPC, 4. Zarządzenia wewn[ętrzne] Dyrektora 1955-1956, Zarządzenie no. 146. Sprawa: rozszerzenie kompetencji rad oddziałowych, 5 października 1956 r. [Internal Ordinances of the manager from the years 1955-1956; Ordinance no. 146; Case: department boards' competence extension], There were also voices that creation of Branch Office Councils in large workplaces contributed to formation of another organization of the administration management, which in turn hindered the decision making process. See: 
The last ones acted on a legal validity of Decree from February 6, 1945 about forming Works Councils and one of its tasks was cooperation with the unit management in regulation of personal matters, i.e. employing and dismissal from the work, and mediation in case of conflicts between the employee and employer. This document was slightly amended with Decree from January 16, 1947. ${ }^{22}$ After entry into force of the Act from November 19, 1956 about Council Workers, their cooperation with Works Councils in important issues concerning unit function was desirable, including social and welfare matters. ${ }^{23}$ Next it replaced with the Act from December 20, 1958 about the Workers Self-government. ${ }^{24}$

In compliance with two-week notice period in the tobacco product branch Zofia Regulska was also dismissed from the work. She appealed with this decision to CDAB. During the board meeting they presented facts, which were consequence of Regulska dismissal. She left willfully (and recklessly) the plant during working hours (although earlier she asked for pass, but didn't receive it). As it turned out, the worker had already been punished orally and in writing for indiscipline, not to say twice dismissed and hired back. She wrote also promise of improvement; however, in the opinion of management, still was undisciplined and didn't care for repeated admonitions. ${ }^{25}$

Although the minutes of CDAB meeting in Regulska case wasn't kept, but as it is known the verdict of boards was disadvantageous for her, since she next appealed to the Main Board of Food Industry Trade Union. ${ }^{26}$ The

Hirszowicz Maria, Morawski Witold, Niektóre problemy samorządu robotniczego [Selected problems of workers' councils], Praca i Zabezpieczenie Społeczne, no. 8, 1962, p. 16.

${ }^{22}$ Dekret z dnia 6 lutego 1945 r. o utworzeniu Rad Zakładowych [Decree of February 6, 1945 on the creation of factory boards], Journal of Laws [Dz. U.] 1945, no. 8, item 36 and Dekret z dnia 16 stycznia 1947 r. o zmianie dekretu z dnia 6 lutego 1945 r. o utworzeniu Rad Zakładowych [Decree of January 16, 1947 changing decree of February 6, 1945 on the creation of factory boards], Journal of Laws [Dz. U.] 1947, no. 24, item 92.

${ }^{23}$ Ustawa z dnia 19 listopada 1956 r. o radach robotniczych [Act of November 19, 1956 on workers' boards], Jouranal of Laws [Dz. U.] 1956, no. 53, item 238.

24 Ustawa z dnia 20 grudnia 1958 r. o samorządzie robotniczym [Act of December 20, 1958 on workers' councils], Journal of Laws [Dz. U.] 1958, no. 77, item 397.

${ }^{25}$ ANKES, ZPTK, WPC, 342 ZKR, Załącznik do protokołu [z obrad Zakładowej Komisji Rozjemczej przy Wytwórni Papierosów „Czyżyny” w Czyżynach] [Attachment to the minutes of the Company Disputes Committee session in the "Czyżyny" cigarette factory].

26 ANKES, ZPTK, WPC, 342 ZKR, Pismo przewodniczącego Komisji Rozjemczej przy Wytwórni Papierosów "Czyżyny” L. Ulmana do Zarządu Głównego Związku Zawodowego Pracowników Przemysłu Spożywczego w Warszawie, 1 marca 1955 r., [Letter of the chair of the Company Disputes Committee in the "Czyżyny" cigarette factory, 
management board before taking a decision asked the Czyżyny Plant to supplement the documentation i.e. to provide information, whether the petitioner was dismissed from the work with a two-week notice period, or with immediate effect. ${ }^{27}$ In response CDAB informed the Main Board that it was the first option. What's interesting, they also informed that Regulska again was hired as a result of intervention of the Municipal Board of Polish United Workers Party in Cracow and with consent of the plant director. ${ }^{28}$

However, the Main Board approved CDAB statement by the Tobacco Plant in Czyżyny from February 22, 1955, rejecting a motion of person concerned to withdrawal the employment termination. In grounds they emphasized that the unit terminated the employment with petitioner in compliance with statutory notice period. In addition, they added that the enterprise management is responsible for personnel politics, and dispute adjudication boards in units didn't have impact and insight into its action, of course provided that didn't violate effective laws and regulations. ${ }^{29}$

Also a mechanic Zbigniew Turcza of the cigarette branch turned to $\mathrm{CDAB}$, since the management board terminated his employment on March 24,1956 . He asked for a consideration of the entire his matter. He questioned a report filed by one of workers that on March 22, 1956 had been at the work intoxicated. As confirmation he pointed out to very good operation of the machines, which were under his supervision, and provided names of witnesses. However, as for accusing him of frequent drinking vodka, he added that it was due to serious pulmonary disease, which he had as a result of work in the tobacco industry. Apart from that repeated-

L. Ulman, to the General Board of the Food Industry Workers' Trade Union in Warsaw, March 1, 1955], L.dz 13/55.

27 ANKES, ZPTK, WPC, 342 ZKR, Pismo sekretarz Zarządu Głównego Związku Zawodowego Pracowników Przemysłu Spożywczego w Warszawie H. Grabowskiej do Zakładowej Komisji Rozjemczej przy Wytwórni Papierosów w Krakowie-Czyżynach, 17 marzec 1955 r., [Letter of the secretary of the General Board of the Food Industry Workers' Trade Union in Warsaw, H. Grabowska, to the Company Disputes Committee in the "Czyżyny" cigarette factory in Kraków-Czyżyny, March 17, 1955], KR-2-1986-55.

28 ANKES, ZPTK, WPC, 342 ZKR, Pismo przewodniczącego Komisji Rozjemczej przy Wytwórni Papierosów "Czyżyny” L. Ulmana do Zarządu Głównego Związku Zawodowego Pracowników Przemysłu Spożywczego w Warszawie, 30 marca 1955 r. [Letter of the chair of the Company Disputes Committee in the "Czyżyny" cigarette factory, L. Ulman, to the General Board of the Food Industry Workers' Trade Union in Warsaw], March 30 1955], act no. $13 / 55$.

29 ANKES, ZPTK, WPC, 342 ZKR, Pismo Zarządu Głównego Związku Zawodowego Pracowników Przemysłu Spożywczego w Polsce do Obywatelki Zofii Regulskiej, 13 kwietnia 1955 r. [Letter of the General Board of the Food Industry Workers' Trade Union in Poland to Ms. Zofia Regulska, April 13, 1955], KR 136/3123/55. 
ly he drank vodka with the woman, who then reported file, as a proof of that he provided witnesses and places where together they drank. Turcza was also accused of stealing cigarettes, which was in his view a downright lie and slander. He denied that was "the leader of gang" (as complainant was supposed to describe him), who managed thefts of cigarettes in the branch. At the end of his conclusion to the board he emphasized that he had been the only breadwinner and father of a small child. ${ }^{30}$

Turcza matter was considered by CDAB during a meeting on April 21, 1956. All witnesses testified that he had been a very good mechanic, who fulfilled duties entrusted without fault. They emphasized simultaneously that he liked alcohol, but none of witnesses seen him drunk at the work. ${ }^{31}$ In issued statement in Turcza case the board stated that dismissing him was right. Charges of drinking alcohol in working hours were rejected as groundless; however other facts placed in personal files of the employee affected on board decision. They included: official notification of one of employees about damage of gear in glue machine by Turcza, failure to comply with labour discipline, unexcused absences and given reprimands. That's all, in the board opinion, qualified the employee Józef Turcza for dismissal. ${ }^{32}$

Another case reported to CDAB concerned the theft, which according to appealing Zofia Kowalska the worker of tobacco production branch, did not take place. Being on the sick leave, she obtained notice from the work, as we read in the letter from L. Logofa the assistant manager of Czyżyny Administrative-Commercial Plant, for "stealing cigarettes from the local production plant". ${ }^{33}$ The worker was surprised with dismissal

30 ANKES, ZPTK, WPC, 342 ZKR, Pismo skierowane przez Zbigniewa Turczę do Komisji Rozjemczej przy Czyżyńskiej Wytwórni Papierosów w Czyżynach, 6 kwietnia 1956 r. [Letter of Zbigniew Turcza to the Company Disputes Committee in the "Czyżyny" cigarette factory, April 6, 1956], rps. [manuscript].

31 ANKES, ZPTK, WPC, 342 ZKR, Protokół rozprawy Zakładowej Komisji Rozjemczej przy Wytwórni Papierosów „Czyżyny” w Czyżynach, 21 kwietnia 1956 r. [Minutes of the hearing of the Company Disputes Committee of the "Czyżyny" company in Czyżyny, April 21, 1956], act no. 8/56.

32 ANKES, ZPTK, WPC, 342 ZKR, Orzeczenie Zakładowej Komisji Rozjemczej przy Wytwórni Papierosów „Czyżyny” w Czyżynach, 21 sierpnia 1956 r. [The decision of the Company Disputes Committee in the "Czyżyny" cigarette factory, August 21, 1956], act no. $8 / 56$.

33 ANKES, ZPTK, WPC, 342 ZKR, Pismo zastępcy dyrektora do spraw administracyjno-handlowych L. Logofa do Obywatelki Kowalskiej Zofii, 3 grudnia 1957 r. [Letter of the deputy manager for administration and trade, L. Logof, to Zofia Kowalska], December 3, 1957], 12010/DP/57. 
and in the letter to the board she related a course of events. On November 26, 1957 she was detained behind the gate of the plant by the officers of Citizen's Militia, who carried out a search and didn't find any cigarettes. However, she was detained, auditioned, and then released from the arrest, in which she spent 48 hours. In application to the board she exactly explained the course of events from that unlucky day. Behind the gate of plant, Maria Drabik waited for her to whom the controller Maria Czyż came up, handing her allegedly a packet of wool, but the one didn't want to take it. In that moment a police officer came up to women and took them for a search. As Kowalska claimed, by her not a single cigarette was found, and the dismissal from work it's a consequence of the intrigue in which unsympathetic employees of the plant were involved, i.e. the commander officer of the industrial guard and one of controllers, about which she knew that were fellow drinkers, and from which she could smell an alcohol every day. Moreover, the controller wanted, according to Kowalska, to have an affair with her (she was a divorcee), but she disagreed, since he had his family and nine children. She reminded that in numerous previous inspections to which was reported, never stated that she steals cigarettes. She also supposed that the controller Czyż whom no relations joined her, apart the work, could take part in prepared "conspiracy" out of jealousy, because she liked the controller Bronisław Czubryt, who often after work came back home with Kowalska, since they went in one direction. ${ }^{34}$

Unfortunately, lack of documents doesn't allow to state, how this criminal-romance story ended and how the fates of employees went further. We can find only a handwritten note of L. Logofa, addressed to CDAB to withdraw disciplinary termination. ${ }^{35}$ However, the entire situation is a next reflection of everyday industrial factory function in its dimension, thus not strictly production, but equally important for people working in the unit.

Here arises a question, whether above relations of Zofia Kowalska and earlier accusing person Turca it is possible to treat as a proof of existence in the unit of certain unofficial employee connections. ${ }^{36}$ It seems very

34 ANKES, ZPTK, WPC, 342 ZKR, Pismo Zofii Kowalskiej do Komisji Rozjemczej przy Wytwórni Papierosów "Czyżyny” w Czyżynach, 5 grudnia 1957 r. [Letter of Zofia Kowalska to the Company Disputes Committee of the "Czyżyny" cigarette factory, December 5, 1957].

35 ANKES, ZPTK, WPC, 342 ZKR, Odręczna notka L. Logofa do Komisji Rozjemczej [Handwriten note of L. Logof to the Disputes Committee].

36 See: Iwanowska Anna, Federowicz Michał, Żukowski Tomasz, Ład administracyjny $w$ zarządzaniu gospodarka [Administrative order in industry management], [in:] Człowiek w systemie gospodarowania [Man in the economic system], vol. 1, PTE, Białystok 1986, p. 141. 
probable, taking into account that such connections existed in all sorts of units, and were created unofficial employee "caucuses", granting oneself additional entitlements or privileges, which in accordance with the law or company regulations weren't entitled to them. ${ }^{37}$ It is worthwhile to mention that directly about the existence of "caucuses" or "dictatorships" in Czyżyny plant, told the first secretary of Basic Party Organization Michał Smiech during one of conferences. It was supposedly created by directors Edward Nowak and Modest Lipecki, chairman of the Works Board Henryk Siemko and second secretary of Basic Party Organization Wojciech Kowal. ${ }^{38}$

Considerable part of employees for participation in caucus, or the group, exerting pressures of different kind on the crew accused Maria Sewiołek, worker of the personal section with two-year experience in the plant. Her attitude was definitely negatively assessed by the plant crew during a meeting held on October 31, 1956, when she was accused for an improper attitude toward the crew, denunciation, writing anonymous letters and taking part in terrorizing the crew. ${ }^{39}$ In this last action other worker helped her - Maria Nonckiewicz, who in May 31, 1955 became the first secretary of Basic Party Organization in CZCF. ${ }^{40}$ She was described as "chieftain" of the plant, before which the entire crew shivered. ${ }^{41}$

37 The problem of functioning in industrial plants in a period of Polish People's Republic informal employee groups was interestingly presented by Maciej Tymiński. See: Tymiński Maciej, Funkcjonowanie klik w zakładach przemystowych (1950-1970) [Functioning of cliques in industrial plants (1950-1970)], Kultura i Społeczeństwo, no. 4, 2002, p. 109131.

38 Archiwum Narodowe w Krakowie. Oddział IV [National Archive in Kraków, Department no. 4] (ANKIV), Komitet Dzielnicowy PZPR Nowa Huta [PZPR (Polish United Worker's Party) District Committee in Nowa Huta] (KD PZPR), sign. 284, Protokół zebrania wyborczego POP przy Wytwórni Papierosów "Czyżyny” odbytego dnia 31 maja 1955 r. w świetlicy wytwórni [Minutes of the election meeting of POP (Basic Party Organization) in the "Czyżyny" cigarette factory of May 31, 1955, which took place in the factory common-room], p. 5.

39 ANKES, ZPTK, ZPTwK, 24/40 PMT, no. 1-292: Pisma okólne, sprawozdania. Lata 1954-1957; wnioski dotyczące reorg[anizacji] W[wytwórni] P[papierosów] Czyżyny [Bulletins and reports. Years 1954-1957; conclusions concerning the reorganization of the "Czyżyny" cigarette factory] (POSW), Protokół zebrania załogi Wytwórni Papierosów "Czyżyny" w dniu 31 października 1956 r. [Minutes on the meeting of the "Czyżyny" cigarette factory staff of October 31, 1956], p. 2.

40 ANKIV, KD PZPR, sign. 284, Wykaz członków wybranego kierownictwa partyjnego POP przy WPC Czyżyny dn. 31 maja 1955 r. [List of selected Basic Party Organization management members at the "Czyżyny" cigarette company in May 31, 1955].

41 ANKIV, KD PZPR, sign. 284, Protokół zebrania wyborczego odbytego w dniu 3 lipca 1956 r. Podstawowej Organizacji Partyjnej przy Wytwórni Papierosów "Czyżyny" 
Sewiołek was removed from the position and transferred to manual workers, as well as postulated of dismissal was issue with three-month notice period. ${ }^{42}$ The management board approved decisions of the crew. ${ }^{43}$

In a letter sent to $\mathrm{CDAB}$, Sewiołek complained that she's accused for so serious allegations. With indignation she wrote that they were defamatory and untrue:

As for anonymous letters [we can read] I have too opened character and I care very much for my honor, to humiliate myself (even in own eyes) and to write anonymous letters. $^{44}$

She connected her personal situation with a period of October thaw, suggesting that somebody, who didn't liked her, used the time cynically, when peculiarly it was possible to have an influence on a psyche of people. She wrote farther:

Matter of democratization the country isn't a matter of depriving the mother with child of bread, completely unjustly, without any credibility of posed allegations. ${ }^{45}$

CDAB didn't considered Sewiołek matter, from a letter we can see a handwritten note that it is rejected to be settled, since it's beyond the scope of board function. ${ }^{46}$

An important component of staff salaries were all sorts of bonuses, which can also be seen in terms of employee benefits; and their deductions extremely negatively affected employees. Such an example was in case of the employee of cigarettes production branch, Mieczysław Drabik. His bonus for August 1956 in amount of 100\% was reduced by the management board. In grounds we read that the employee was punished for

[Minutes on the election meeting of July 3, 1956 of the Basic Party Organization of the "Czyżyny" cigarette company], p. 2.

42 ANKES, ZPTK, ZPTwK, 24/40 PMT, POSW, Protokół zebrania załogi Wytwórni Papierosów "Czyżyny" w dniu 31 października 1956 r. [Minutes on the meeting of the "Czyżyny" cigarette company staff of October 31, 1956], p. 2.

43 ANKES, ZPTK, ZPTwK, 24/40 PMT, POSW, Protokół posiedzenia kolektywu zakładowego $\mathrm{w}$ dniu 8 listopada $1956 \mathrm{r}$. [Minutes of the company collective session of November 8,1956$]$.

44 ANKES, ZPTK, WPC, 342 ZKR, Pismo Marii Sewiołek do Komisji Rozjemczej przy Wytwórni Papierosów "Czyżyny”, 5 lutego 1957 r. [A letter from Maria Sewiołek to the Disputes Committee of the "Czyżyny" cigarette company, February 5, 1957], act no. $3 / 57$.

${ }^{45}$ Ibidem.

${ }^{46}$ Ibidem. 
failure to comply with provisions of the socialist labour discipline, which hindered the work of management board. ${ }^{47}$ Drabik appealed from the decision to $\mathrm{CDAB}$, arguing that deduction of the entire bonus (i.e. 429 PLN) was too severe punishment for missing one working day. He also added that in the unit he had worked three years, and apart from that unlucky day he didn't miss a single one. ${ }^{48}$ During board meeting the branch manager of cigarettes production Stanisław Gajda testified that on that day two mechanics didn't come to work, for which responsibility was charged Drabik. Therefore he proposed 30\% of bonus deduction for August, and the company team raised penalty up to $100 \%$. Henryk Siemko, mechanic of the cigarettes production branch stated that badly happened, since they didn't reach an agreement previously with the company team, because the matter probably would be differently solved. Director of the plant, Adam Mikulski, stated that penalty of $100 \%$ bonus deduction was too harsh for a single offense. Drabik additionally explained that on the day before his absence, a friend comes to him from Radom and they drank too much alcohol, so he could not come to work intoxicated. The employee admitted that did wrong and expressed remorse.

Board unanimously canceled the decision of the company team of $100 \%$ bonus deduction, and kept the conclusion of the team of cigarettes production branch about $30 \%$ of bonus deduction and in connection to pay the employee $70 \%$ of bonus. ${ }^{49}$

Also another case concerned deduction of bonus in the plant. Three workers of the packing room branch - Adela Stankiewicz, Elżbieta Malinowska and Genowefa Grymek were punished with 30\% bonus deduction for wrong packaging cigarettes. They regarded such a decision as highly hurting, because it happened for the first time. In their view a reprimand would be enough with warning, comparatively $10 \%$ of bonus deduction.

47 ANKES, ZPTK, WPC, 342 ZKR, Pismo zastępcy dyrektora do spraw administracyjno-handlowych Wytwórni Papierosów „Czyżyny” L. Logofa do M. Drabika pracownika fizycznego wytwórni Papierosów "Czyżyny”, 28 sierpnia 1956 r. [A letter of the deputy manager for administration and trade of the "Czyżyny" cigarette company, L. Logof, to M. Drabik, a factory worker at the "Czyżyny" cigarette company, August 28, 1956].

48 ANKES, ZPTK, WPC, 342 ZKR, Pismo M. Drabika do Komisji Rozjemczej przy Wytwórni Papierosów "Czyżyny”, 10 listopada 1956 r. [A letter from M. Drabik to the "Czyżyny” cigarette company Disputes Committee, November 10, 1956], act no. 21/56.

49 ANKES, ZPTK, WPC, 342 ZKR, Protokół rozprawy Zakładowej Komisji Rozjemczej przy Wytwórni Papierosów "Czyżyny” w Czyżynach, 21 listopada 1956 r. [Minutes of the session of the Disputes Committee of the "Czyżyny" cigarette company in Czyżyny, November 21, 1956], act no. 21/56. 
They turned with a request for help to CDAB. ${ }^{50}$ They were called for the board meeting on October 11, 1956 at $2.00 \mathrm{pm}^{.1}$

During the meeting it turned out that Malinowska and Grymek were earlier punished by the management board. Stankiewicz stated that when she came to work there were already 48 badly packed bags of cigarettes "Giewont". In her view it was a fault of the machine, about which as a matter of fact she reported to the mechanic, who didn't reacted. This accident took place on August 16, 1956, and the team punished the worker at the end of September without prior interrogation. Malinowska and Grymek confirmed her words. The one last added that indeed she was earlier punished in July of this year, just after a few working days in the unit, but as she added not for her misdeed, only other employees, but nobody proved her guilt. Branch manager Jan Muszel stated that defect appeared only from the workers fault. Mechanic and chairman of the Branch Office Councils Stanisław Potocki also assigned the fault to operation of the machine, adding in addition that this kind of defects still appeared on the branch. Confirmed it Antoni Zajączkowski, manager of the packing room, who admitted, that was also punished by the director of plant with bonus deduction. ${ }^{52}$

The next group of employee problems was associated with a way of conducting body search while leaving the work. A narrow employee group could enjoy the privilege of exemption from this, sometimes unpleasant for employees, although inevitable obligation. According to the Central Board of Tobacco Industry (CBTI, Centralny Zarząd Przemysłu Tytoniowego) order to the search were subject all manual workers and office workers, with exception of the executive director and his two deputies, chief accountant, chairman of the Works Council, secretary of the Basic Party Organization and head of the personal section. Moreover, from the search were also exempted delegations of superior authorities and em-

50 ANKES, ZPTK, WPC, 342 ZKR, Do Komisji Rozjemczej przy Wytwórni Papierosów „Czyżyny”. Prośba [Adeli Stankiewicz, Elżbiety Malinowskiej i Genowefy Grymek], 28 września 1956 r. [To the "Czyżyny" cigarette company Disputes Committee. A request of Adela Stankiewicz, Elżbieta Malinowska and Genowefa Grymek, September 28, 1956].

51 ANKES, ZPTK, WPC, 342 ZKR, Wezwanie na posiedzenie Zakładowej Komisji Rozjemczej, 6 października 1956 r. [Call to a session of the Company Disputes Committee, October 6, 1956].

52 ANKES, ZPTK, WPC, 342 ZKR, Protokół rozprawy Zakładowej Komisji Rozjemczej przy Wytwórni Papierosów "Czyżyny” w Czyżynach, 11 października 1956 r. [Minutes on the session of the "Czyżyny" cigarette company in Czyżyny Disputes Committee, October $11,1956]$, act no. $20 / 56$. 
ployees of other authorities and offices, which need to enter the site of tobacco industry was justified with an official delegation, or legitimacy. ${ }^{53}$

The way of carrying out a search in the unit didn't appeal to the worker Helena Iszczukiewicz, and since the company team reduced her bonus for inappropriate behavior during search, she decided to present the matter to CDAB. During CDAB meeting she related the entire incident: she was dressed in a summer dress, and as a result of improper search by the controller Antonia Kocura, she sustained bodily injury. Iszczukiewicz added that in her view, only the gynecologist could conduct such a search in the room allocated for this purpose, rather than public, where many men stood and arranged a laughing stock from the entire scene. She denied the argument that insulted the controller with words: "are you relieved". In any case, the controller turned to the foreperson of controllers who took back Iszczukiewicz pass to access the unit. Next day the company team considered that case, since the controller filled report, but Iszczukiewicz as the defendant wasn't invited. As a result they decided to deduct $25 \%$ of the employee bonus for inappropriate behavior during search. ${ }^{54}$

The worker disagreed to take her bonus in amount of 100 PLN and appealed to $\mathrm{CDAB}$ from the decision of company team. In grounds she stated that the controller was lying, because she didn't offend her at all, and a way of search offended her personal dignity..$^{55}$ During CDAB meeting one of women - Wiktoria Hodur confirmed that two days earlier the same controller also treated her similarly as Iszczukiewicz. Also a member of the board -senior laboratory technician Zofia Kolarz stated that she also was searched in a brusque way. Chief engineer Karol Fyda admitted that indeed the search should not be carried out in a wrong way, but on the other hand it isn't possible to decreases its meaning and importance. Controller's work, he added, was very ungrateful, even for alone searching. After hearing the parties, the adjudicating board on a secret meeting, unanimously overruled the decision of the company team directed to

53 ANKES, ZPTK, WPC, 2. Zarządzenia wewnętrzne 1953-1954 [Internal Ordinances 1953-1954], vol. 2; Zarządzenie wewnętrzne [Internal Ordinance], no. 28/53, 8 kwietnia 1954 r. See also: ANKES, ZPTK, ZPTwK, 24/21, Okólnik no. 1/56 w sprawie przeprowadzenia rewizji w zakładach przemysłu tytoniowego, 22 sierpnia 1956 r. [Bulletin no. 1/56 on the audit in the cigarette plant, August 22, 1956], no. 1203/Pf/WOP/56.

54 ANKES, ZPTK, WPC, 342 ZKR, Protokół rozprawy Zakładowej Komisji Rozjemczej przy Wytwórni Papierosów „Czyżyny” w Czyżynach, 2 lipca 1956 r. [Minutes on the session of the "Czyżyny" cigarette company in Czyżyny Disputes Committee, July 2, 1956], act no. $14 / 56$.

55 Ibidem. 
Helena Iszczukiewicz, regarding it as unfair and hurting. However, the matter of improper women search was submitted to the administration management for regulation. ${ }^{56}$

In the Polish tobacco industry, receiving a bonus by employees, who had an appropriate work experience, was included in employee privileges. However, not always this appropriate work experience was an obvious matter. E.g. the employee with many years of experience in tobacco industry and installation electrician of the plan in Czyżyny, Jerzy Spirydowicz, turned in this matter to $\mathrm{CDAB}$. He wanted to include to the continuity of work years with his participation in Armed Forces of the Republic of Poland in 1939-1946. Spirydowicz before the war in 1929-1939 uninterruptedly worked in the Polish Tobacco Monopoly (PTM), and then received call-up. He participated in the September Campaign, then with the army unit was interned to Romania, where he was sent to France, and after its capitulation to England, where was integrated into the aviation service of Armed Forces of the Republic of Poland. After the end of war, when repatriations began, he decided to return to Poland and came back in July 1946. He settled in Łódź, where also reported to the Regional Military Draft Office Łódź-City and was demobilized based on order of the commander-in-chief of Armed Forces of the Republic of Poland no. 0181 from August 8, 1945. ${ }^{57}$

Next he reported to PTM management in Eódź for re-hired as the electrician, and the one referred him to PTM plant in Wodzisław, where he began work in November 1946. In the next year was transferred to tobacco and snuff plant in Racibórz. He worked there until February 1953, and then was transferred to CZCF. In relation to granting one-off bonuses to employees, whose work experience was 25 years, on the distinguished list was Spirydowicz, but he didn't receive a monetary bonus. In the personal section of plant he found out that CBTI in Warsaw rejected his motion, justifying with the fact that his service in Armed Forces of the Republic of Poland in the West doesn't rank among seniority and it's an addition-

\footnotetext{
56 ANKES, ZPTK, WPC, 342 ZKR, Protokół rozprawy...,2 sierpnia 1956 [Minutes on the session..., August 2, 1956].

57 ANKES, ZPTK, WPC, 342 ZKR, Pismo Jerzego Spirydowicza do Komisji Rozjemczej przy Wytwórni Papierosów „Czyżyny”, 23 sierpnia 1956 r., rps. [A letter from Jerzy Spirydowicz to the "Czyżyny" cigarette company Disputes Committee, August 23, 1956, manuscript] It is worthwhile to add that on August 18, 1945 there was carried out division of the country territory to supplement areas and 86 Regional Military Draft Offices were formed. See: Babula Julian, Wojsko polskie 1945-1989. Próba analizy operacyjnej, Dom Wydawniczy Bellona, Warszawa 1998, p. 330-331.
} 
al obstacle to receive the bonus for 25 years of work experience. The employee turned to $\mathrm{CDAB}$ with enquiry, whether decision of Warsaw head office was right. ${ }^{58}$

The board considered Spirydowicz application as right. As the legal basis of decision was Resolution of the Council of Ministers from June 21, 1950, which predicted that service in the Polish Army in 1939-1945 years didn't cause a break in the continuity of work. ${ }^{59}$ According to it the employee had to prove circumstances entitling to application of the resolution provisions. Therefore, during CDAB meeting September 28, 1956 Spirydowicz presented documents confirming his military service in years of the war. Next after reading out by the board chairman the older master of Tadeusz Orczyk of recalled resolution and brief discussion, they decided to include years spent by the employee in Polish Army to work experience. ${ }^{60}$

Employees reported to CDAB also with a sense of harm and injustice, which experienced in the workplace on the part of management or work-

58 ANKES, ZPTK, WPC, 342 ZKR, Pismo Jerzego Spirydowicza... [A letter from Jerzy Spirydowicz...]. In two first years of the plan function, i.e. in 1953 and 1954, in summary of social security benefits, not a single award for persons celebrating anniversary was noted. In the plan for 1955 there were five of such awards. See: ANKES, ZPTK, WPC, 26. Plan zatrudnienia i płac na rok 1955, Plan świadczeń socjalnych na rok 1955, 16 II 1955 r. [Employment and remuneration plan for the year 1955. Social benefits plan for the year 1955, February 16, 1955].

${ }^{59}$ See: Uchwała Rady Ministrów z dnia 21 czerwca 1950 r. w sprawie określenia przerw w zatrudnieniu oraz zmian zakładu pracy, które nie mają skutków, pozbawiających lub ograniczających prawa pracownika do korzystania z urlopu [The Council of Ministers Act of June 21, 1950 on determining breaks in employment and shifts in the plant, which do not result in limiting the employees' right to leave or the deprivation thereof], M. P. 1950, no. A-77, item. 888.

${ }^{60}$ ANKES, ZPTK, WPC, 342 ZKR, Protokół rozprawy Zakładowej Komisji Rozjemczej przy Wytwórni Papierosów "Czyżyny", 28 września 1956 r. [Minutes of the "Czyżyny" cigarette company Disputes Committee session, September 28, 19956]. Also in later years appeared a lot of doubts as to ranking breaks in the work caused by the war among working hours for employees seeking for jubilee awards for the seniority. Therefore, the Main Board of Food Industry Trade Union explained, based on the opinion of State Commission of Pays that it is necessary to follow the principle to rank among continuity of the work and working time: period of the stay in captivity and military camps, detaining persons being on duty in the Polish Army, in Polish military formations in the USSR created after May 13, 1943, which ran the fight with Nazi invader, in the USSR army and Polish military formations in the West from September 1, 1939 to February 12, 1946. See: ANKES, ZPTK, ZPTwK, 24/22, no. 3: Zatrudnienie i płace 1956-1958 [Employment and salaries 1956-1958], Pismo Zarządu Okręgu Związku Zawodowego Pracowników Przemysłu Spożywczego $\mathrm{z}$ dnia 23 sierpnia $1958 \mathrm{r}$. [A letter of the district management of the Food Industry Trade Union of July 23, 1958], L.dz. 2993/Ekon./58. 
ers self-government. They believed that persons on managerial positions, Works Councils and Council Workers used their powers and privileges not to improve the employee and working conditions, but on the contrary, hinder, and to written request for explanations they didn't answer.

This way believed an employee Józef Hajto towards which Council Workers approved termination from work for three months, after which he was supposed to be re-employed, but already on other positions and with a lower salary, i.e. from the position of master craftsman on the tobacco production branch was supposed to be transferred to the magazine of raw material. Employee with this degradation felt very hurt. In the application to the board he wrote: "it makes me a huge disservice as moral, psychological and financial".${ }^{61} \mathrm{He}$ had a grudge against the unit that they didn't try to understand his family position, i.e. three of children from 5 up to 15 years and chronically sick wife. Alone he was also a sick person (had a duodenal ulcer). He added:

I think that the management realizes that work in the magazine of raw material it is not simple, there is needed a physically strong, healthy man. ${ }^{62}$

The matter after all was settled amicably with the CZCF director, Adam Mikulski. Hajto was transferred to the magazine of free tobacco plants on foreperson position. ${ }^{63}$

It is hard for a clear summary of the issues of employee privileges in the Polish tobacco industry in a period of Polish People's Republic on example of Cracow plants, considered in CDAB and workers self-management context. The above article constitutes only a starting point for further in-depth studies covering employee issues in all tobacco industry in Poland. Described privileges of determined employee groups arose largely from the statute law, although not without meaning carried out its interpretation, by listed earlier employee members. Apart from that, it was possible to notice the sign of appropriating privileges by determined em-

61 ANKES, ZPTK, WPC, 342 ZKR, Prośba Józefa Hajty do Komisji Rozjemczej przy Dyrekcji Wytwórni Papierosów w Czyżynach, 19 lutego 1958 r. [A request from Józef Hajto to the "Czyżyny" cigarette company Disputes Committee, February 19, 1958], no. 3/58, rps. [manuscript].

62 Ibidem.

63 ANKES, ZPTK, WPC, 342 ZKR, Dopisek odręczny T. Orczyka na prośbie J. Hajty z pieczątką Zakładowej Rady Rozjemczej, 20 lutego 1952 r. [A hand-written note by T. Orczyk on the request from J. Hajto with a stamp of the Company Disputes Committee, February 20, 1952], rps. [manuscript]. 
ployees groups not-arising from the existing law, but being a sign of aspirations to ensure a higher position for oneself in the unit through certain acquaintances and in consequence achieving common benefits, etc. informally.

Andrzej Synowiec - PhD in history (2005). Assistant professor at the Economic and Social History Department, The Institute of History of the Jagiellonian University in Kraków. Areas of interests: industrial and social history (19th and 20th century), tobacco industry, railways, quantitative methods in historical and economic studies. Author of numerous articles and a monograph Przemyst tytoniowy w Polsce w okresie pierwszego planu pięcioletniego (1956-1960), Kraków 2014, pp. 302 among others. 
